\title{
PRO-OXIDANTS AND ANTIOXIDANTS IN RETINOPATHY OF PREMATURITY
}

\author{
Lidija Banjac ${ }^{1}$, Goran Banjac², Jelena Kotur-Stevuljević3 ${ }^{3}$, Vesna Spasojević-Kalimanovska ${ }^{3}$, \\ Tamara Gojković ${ }^{3}$, Nataša Bogavac-Stanojević ${ }^{3}$, Zorana Jelić-Ivanović ${ }^{3}$ and Gorica Banjac ${ }^{4}$ \\ ${ }^{1}$ Department of Neonatology, Clinical Center of Montenegro, Podgorica, Montenegro; \\ ${ }^{2}$ Institute of Children's Diseases, Clinical Center of Montenegro, Podgorica, Montenegro; \\ ${ }^{3}$ Institute of Medical Biochemistry, Faculty of Pharmacy, University of Belgrade, Belgrade, Serbia; \\ ${ }^{4}$ Narodni front Clinic of Gynecology and Obstetrics, Belgrade, Serbia
}

\begin{abstract}
SUMMARY - Premature infants are susceptible to oxidative stress that causes neonatal disease such as retinopathy of prematurity (ROP). Oxidative stress is an imbalance between the production of pro-oxidants and the ability of the body to detoxify their harmful effects by antioxidants. The proliferative phase $2 \mathrm{ROP}$ occurs at around $33^{\text {rd }}$ postmenstrual week (pmw). The purpose of our study was to evaluate the pro-oxidant/antioxidant status in preterm infants at $33^{\text {rd }} \mathrm{pmw}$. The study included 59 premature infants. ROP was classified according to the International Classification of Retinopathy of Prematurity. Total oxidative status (TOS), total antioxidant status (TAS), malondialdehyde (MDA) and paraoxonase 1 (PON1) activity were determined spectrophotometrically. The values of the prooxidants TOS and MDA were significantly higher in infants with ROP as compared to infants without ROP ( $<<0.05$ both). There were no significant differences in the values of TAS and PON1 between the infants with and without ROP. According to study results, TOS and MDA are good markers of oxidative stress, whereas TAS and PON1 activity are unreliable in assessing antioxidant protection.
\end{abstract}

Key words: Reactive oxygen species; Antioxidants; Retinopathy of prematurity; Infant, premature; Oxidative stress

\section{Introduction}

Premature infants belong to the category of 'vulnerable newborns' because of the large proportion of total perinatal morbidity and mortality. They are especially susceptible to oxidative stress, which affects a variety of organs, often simultaneously, causing neonatal diseases such as retinopathy of prematurity (ROP), bronchopulmonary dysplasia, necrotizing enterocolitis, intraventricular hemorrhage, periventricular leukomalacia, respiratory distress syndrome, intrauterine growth retardation and congenital malformation. These

Correspondence to: Lidija Banjac, PhD, Djoka Miraševića M1 53/7, Podgorica, Montenegro

E-mail:drbanjac@t-com.me

Received August 30, 2017, accepted December 27, 2017 diseases have also been reported to be oxidative stressrelated neonatal diseases ${ }^{1,2}$.

Retinopathy of prematurity (ROP) is the most important disease of prematurity and a major cause of blindness in children. ROP continues to be the leading cause of lifelong visual impairment among children in developed countries ${ }^{3}$. ROP occurs in two phases. The ischemic phase 1 begins after premature birth with delayed retinal vascular growth. The proliferative phase 2 , characterized by pathologic neovascularization, occurs around $33^{\text {rd }}$ postmenstrual week $(\mathrm{pmw})^{4-8}$.

Oxidative stress is imbalance between the production of pro-oxidants and the ability of the body to detoxify their harmful effects through neutralization by antioxidants. The process of birth itself is an oxidative challenge for the newborn. Sharp postnatal transition from intrauterine environment with a relatively low 
oxygen content into an environment with significantly higher oxygen content exposes the infant to oxidative stress, which is emphasized in premature infants due to low efficiency of antioxidant protection ${ }^{9}$. In premature infants, autoregulation of the blood network of retina is adequate in a narrow range of perfusion pressure. The absence of autoregulation leads to hyperoxia of retina ${ }^{10}$. Disturbance in the equilibrium of pro-oxidants and antioxidants initiates an inflammatory process in retinal tissue leading to development of ROP ${ }^{11,12}$.

Free radicals are reactive and short-lived species so that direct measurement is usually not possible. However, hundreds of reactive oxygen species are known to be derived from the interaction of free radicals with biomolecules ${ }^{1}$.

Alternatively to measurements of oxidation products, a test measuring total oxidative status (TOS) was recently developed ${ }^{13}$. Malondialdehyde (MDA) is the end product of lipid peroxidation and a good marker of oxidative stress. This aldehyde is a highly toxic molecule. Its interaction with DNA and proteins has often been referred to as potentially mutagenic and atherogenic $^{12,14,15}$.

Total antioxidant status (TAS) is not just a simple sum of the individual activities of antioxidant substances. It is actually a dynamic system of interdependent individual serum antioxidant parameters. TAS assay has been designed to determine the overall antioxidant power of samples contributed by antioxidants and their interactions. Evaluation of TAS in body fluid has been used as one of the biological markers for monitoring oxidative stress in humans ${ }^{16}$.

Paraoxonase (PON) is a $\mathrm{Ca}^{2+}$-dependent enzyme that is synthesized in the liver and is found in various tissues and plasma. The enzyme takes place in the structure of high-density lipoprotein (HDL) in plas$\mathrm{ma}^{17}$. PON1 has antioxidant property because it prevents the increase of reactive oxygen species quantity by hydrolyzing lipid peroxidation products. It also protects cell from damage caused by oxidative stress ${ }^{18}$. PON family members were upregulated in late-gestation human fetuses and are a candidate therapeutic in premature human infants ${ }^{19}$.

Studies have confirmed that oxidative stress leads to tissue damage during pregnancy, and clinical practice has confirmed that the application of antioxidants can prevent and reduce the diseases caused by oxidative stress ${ }^{20-22}$.
The purpose of our study was to evaluate and compare the pro-oxidant/antioxidant status in preterm infants (with and without ROP) at $33^{\text {rd }} \mathrm{pmw}$ (the beginning of phase $2 \mathrm{ROP}$ ) by measuring the TOS, MDA, TAS and PON1 activity.

\section{Materials and Methods}

\section{Study design and patients}

The study (cohort, prospective) was conducted in the Department of Neonatology, Clinical Centre of Montenegro, Podgorica, with parental informed written consent and after institutional ethical clearance. The study included 59 premature infants, gestational age (GA) of 33 weeks or less. Venous blood sample was obtained from every infant included in the study in the $33^{\text {rd }}$ pmw. All parameters were determined at $33^{\text {rd }}$ pmw. Preterm neonates with gross congenital abnormalities were excluded from the study.

Screening for ROP was done by indirect ophthalmoscopy. ROP was classified according to the International Classification (ICROP) and subdivided into 5 stages. Proliferative ROP (ROP+) was defined as stage 3 , stage 4 or stage 5 . These infants required treatment for ROP (laser therapy or anti-VEGF treatment). Infants with correct ophthalmologic findings and moderate ROP (stage 1 and stage 2) were defined as infants without ROP (ROP-).

Ethics Committee of the Clinical Centre of Montenegro in Podgorica approved the study protocol (consent number 03/01-3813/4), in accordance with standard procedures of the Ethics Committee of the Clinical Center of Montenegro and international guidelines for the performance of biomedical research on humans.

\section{Measurement of pro-oxidant markers}

Since the measurement of different oxidant molecules separately is not practical, TOS of a sample was measured. We used Erel's colorimetric method for measuring TOS. The assay is based on the oxidation of ferrous ion to ferric ion. Color intensity, which can be measured spectrophotometrically, is related to the total amount of oxidant molecules present in the sample. The assay is calibrated with hydrogen peroxide $\left(\mathrm{H}_{2} \mathrm{O}_{2}\right)$ and the results were expressed in terms of micromolar hydrogen peroxide equivalent per liter $\left(\mu \mathrm{mol} \mathrm{H}_{2} \mathrm{O}_{2}\right.$ 
$\mathrm{Eq} / \mathrm{L})^{13}$. MDA was determined as a thiobarbituric acid-reacting substance (TBARS) spectrophotometrically. Thiobarbituric acid (TBA) is widely used to measure TBARS of lipid oxidation. TBA reacts with MDA, a product of lipid oxidation, to give a red, fluorescent MDA/TBA adducts with maximum absorbance at $532 \mathrm{~nm}$. The results are expressed in $\mu \mathrm{mol} / \mathrm{L}^{15}$.

\section{Measurement of antioxidant markers}

Total antioxidant status assays have been designed to determine overall antioxidant power of samples. TAS was determined by a modified Erel's method, i.e. a colorimetric test which depends on the production of hydroxyl radical. The results are expressed in $\mathrm{mmol} / \mathrm{L}^{23}$.

We used the principle of spectrophotometric determination of PON1 activity by using paraoxon as substrate. The sample is mixed with a substrate dissolved in a buffer solution, and the product generated by hydrolysis of the substrate is monitored for a certain time at a linear rate and defined temperature. The results are expressed in $\mathrm{U} / \mathrm{L}^{24}$.

\section{Statistical analysis}

Data were presented as mean \pm standard deviation (SD). Kolmogorov-Smirnov test was used to verify the normality of distribution of parameters. In order to analyze statistically significant differences in the mean values of the examined parameters between the groups, Student's $t$ test was used according to data distribution. The existence of statistically significant correlations between variables was confirmed using the Spearman nonparametric correlation. A p-value of less than 0.05 was considered statistically significant.

\section{Results}

Overall, 59 patients were included in the study. ROP was diagnosed in 18 (30.5\%) infants, whereas in 41 (69.5\%) infants ophthalmologic findings were correct or they had moderate ROP.

The mean gestational age (GA) and birth weight (BW) of preterm infants with and without ROP are displayed in Table 1. Student's t-test showed significant difference in GA and BW between infants with and without ROP. Premature infants with ROP had a significantly shorter mean GA $(\mathrm{p}<0.01)$ and lower mean BW $(\mathrm{p}<0.05)$.
Table 1. Mean gestational age and birth weight of premature infants with and without retinopathy of prematurity (ROP)

\begin{tabular}{|l|l|l|l|}
\hline Parameter & $\begin{array}{l}\mathrm{ROP}+ \\
(\mathrm{n}=18)\end{array}$ & $\begin{array}{l}\mathrm{ROP}- \\
(\mathrm{n}=41)\end{array}$ & $\mathrm{p}$ \\
\hline $\begin{array}{l}\text { Gestational age } \\
\text { (weeks) }\end{array}$ & $30.6 \pm 2.1$ & $31.8 \pm 1.4$ & $\mathrm{p}<0.01^{*}$ \\
\hline Birth weight $(\mathrm{g})$ & $1587 \pm 418$ & $1822 \pm 370$ & $\mathrm{p}<0.05^{*}$ \\
\hline
\end{tabular}

Data are expressed as mean \pm standard deviation; continuous variables were compared using Student's t-test; *statistically significant values

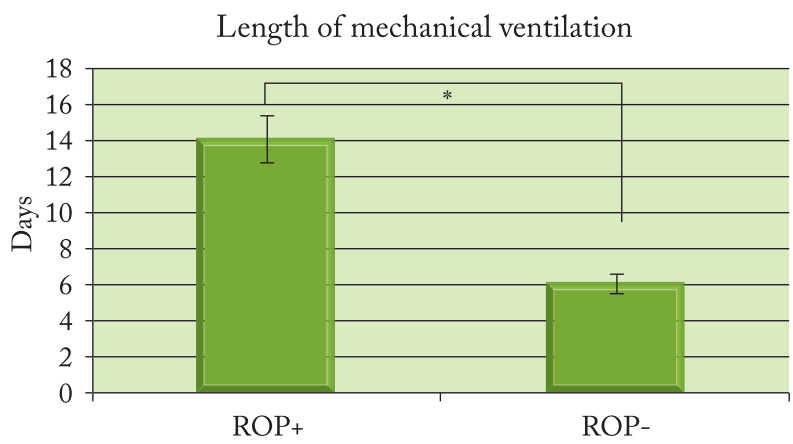

Fig. 1. Length of ventilation in premature infants with and without retinopathy of prematurity (ROP).

*p $<0.05$ ROP+ vs. ROP-

The mean length of mechanical ventilation for infants with ROP was $14.1 \pm 1.31$ days. The mean length of mechanical ventilation for infants without ROP was $6.1 \pm 0.54$ days (Fig. 1). Student's t-test showed a statistically significant difference in the length of ventilation for infants with and without ROP. Premature infants with ROP were ventilated significantly longer $(\mathrm{p}<0.05)$.

The values of the pro-oxidant and antioxidant markers are presented in Table 2. TOS and MDA values in premature infants with ROP were TOS $60.6 \pm 4.88 \mu \mathrm{mol} / \mathrm{L}$ and MDA 1.82 (1.38 to 2.40 ) $\mu \mathrm{mol} / \mathrm{L}$. In premature infants without ROP, the prooxidant markers were lower: TOS $38.6 \pm 3.17 \mu \mathrm{mol} / \mathrm{L}$ and MDA 1.33 (1.16 to 1.52) $\mu \mathrm{mol} / \mathrm{L}$. For both parameters, the difference was statistically significant $(\mathrm{p}<0.05)$.

Premature infants that developed ROP had lower values of TAS $(1.1 \pm 0.64 \mathrm{mmol} / \mathrm{L})$ than infants without ROP $(1.2 \pm 0.69 \mathrm{mmol} / \mathrm{L})$. PON1 activity was higher in infants with ROP $(89.6 \pm 13.0 \mathrm{U} / \mathrm{L})$ than in 
Table 2. Pro-oxidant and antioxidant parameters in patients with and without retinopathy of prematurity (ROP)

\begin{tabular}{|l|l|l|l|}
\hline Parameter & $\begin{array}{l}\text { ROP }+ \\
(n=18)\end{array}$ & $\begin{array}{l}\text { ROP- } \\
(\mathrm{n}=41)\end{array}$ & $\mathrm{p}$ \\
\hline TOS $(\mu \mathrm{mol} / \mathrm{L})$ & $60.6 \pm 4.88$ & $38.6 \pm 3.17$ & $\mathrm{p}<0.05$ \\
\hline MDA $(\mu \mathrm{mol} / \mathrm{L}) *$ & $\begin{array}{l}1.82 \\
(1.32-2.40)\end{array}$ & $\begin{array}{l}1.33 \\
(1.16-1.52)\end{array}$ & $\mathrm{p}<0.05$ \\
\hline TAS $(\mathrm{mmol} / \mathrm{L})$ & $1.1 \pm 0.64$ & $1.2 \pm 0.69$ & $\mathrm{p}=0.55$ \\
\hline PON1 $(\mathrm{U} / \mathrm{L})$ & $89.6 \pm 13.01$ & $60.3 \pm 7.24$ & $\mathrm{p}=0.15$ \\
\hline
\end{tabular}

TOS = total oxidant status; $\mathrm{MDA}=$ malondialdehyde; TAS = total antioxidant status; $\mathrm{PON} 1$ = paraoxonase 1 ; data expressed as mean \pm standard deviation; *data expressed as median values (interquartile range); continuous variables were compared using Student's t test

Table 3. Correlation among antioxidative parameters and gestational age, body weight and malondialdehyde (oxidative stress marker)

\begin{tabular}{|l|l|l|}
\hline Parameter & $\begin{array}{l}\text { TAS } \\
(\mu \mathrm{mol} / \mathrm{L})\end{array}$ & $\begin{array}{l}\text { PON1 } \\
(\mathrm{U} / \mathrm{L})\end{array}$ \\
\hline Gestational age (weeks) & $+0.42^{*}$ & $/$ \\
Birth weight $(\mathrm{g})$ & $+0.55^{*}$ & $/$ \\
Malondialdehyde $(\mu \mathrm{mol} / \mathrm{L})$ & $/$ & $+0.292^{* *}$ \\
\hline
\end{tabular}

Spearman's coefficient $\rho$; TAS $=$ total oxidative status; $\mathrm{PON} 1=$ paraoxonase 1 activity; ${ }^{*} \mathrm{p}<0.05 ;{ }^{* *} \mathrm{p}<0.001$

those without ROP $(60.3 \pm 7.24 \mathrm{U} / \mathrm{L})$. There was no significant difference between the groups $(p=0.55$; $\mathrm{p}=0.15)$.

Spearman's nonparametric correlation showed significant positive correlation between TAS values and GA, and between TAS and BW (Table 3). We also found significant positive correlation between PON1 activity and MDA (Table 3 ).

\section{Discussion and Conclusion}

Newborns, especially premature ones, are at an increased risk of damage mediated by oxidative stress. In the present study, we investigated parameters of oxidative stress (pro-oxidants and antioxidants) in premature infants at $33^{\text {rd }}$ pmw (onset of ROP 2 phase) in order to understand the significance of these parameters in the pathogenesis of ROP.

Pro-oxidants were assessed by measuring TOS and serum MDA. Antioxidant protection was estimated by measuring TAS and PON1 activity. Nowadays, these markers can be measured by simple and sensitive methods.

All infants included in the study $(\mathrm{N}=59)$ were screened for ROP. Timing of the first ROP screening examination was also at $33^{\text {rd }}$ pmw. Laser photocoagulation was used in 18 (30.5\%) infants.

According to our results, premature infants with ROP had a significantly lower BW, shorter GA (Table 1) and longer duration of mechanical ventilation (prolonged oxygen exposure) (Fig. 1).

Studies also confirmed strong connection between short GA, low BW, mechanical ventilation and ROP. It has been reported that premature infants on prolonged ventilation have more chances for development of $\mathrm{ROP}^{12,25,26}$.

We found a statistically significant difference in TOS values between infants with and without ROP. Infants with ROP had significantly higher values of TOS (Table 2).

Studies confirm that vasoconstriction in the retina is an early response to oxygen that can lead to vasoobliteration, neovascularization, and retinal traction (ROP). Disturbance in the equilibrium of oxidant and antioxidant status initiates an inflammatory process in retinal tissue leading to development of $\mathrm{ROP}^{12,27}$.

As shown in Table 2, MDA was also significantly higher in infants with ROP. According to our results, serum concentration of MDA is a good marker of oxidative stress and a ROP predictor.

Studies have shown that elevated levels of serum MDA were associated with adverse respiratory and ophthalmologic outcome in very-low-birth-weight infants ${ }^{14}$. Infants exposed to higher oxidative stress (premature infants, newborns from cesarean section) have a higher level of $\mathrm{MDA}^{28,29}$. Also, significant oxidative stress can be easily assessed by measuring urinary MDA levels ${ }^{30}$. The concentrations of MDA were not predictors of bronchopulmonary dysplasia/death ${ }^{31}$.

In the present study, we did not find a statistically significant difference in TAS values and PON1 activity between the groups. TAS values were lower in infants with ROP, while the values of PON1 activity were even higher in infants with ROP (Table 2).

Studies confirm that inadequate TAS is associated with development of various pathologic conditions including hypoxic injury and $\mathrm{ROP}^{32}$. Decreased maternal serum PON1 levels may also have a role in preterm 
birth $^{33}$. There are a limited number of studies on preterm infants, which evaluated PON1 levels, especially in infants with ROP.

Our results showed positive correlation between MDA and PON1 (Table 3), which made us think of the possible compensatory increase in $\mathrm{PON} 1$ as a protective factor. PON1 plays an important role as an antioxidant in preventing oxidation of low-density lipoproteins $^{34}$.

Our study showed the level of oxidants to correlate significantly with the development of ROP. Our results did not confirm statistically significant betweengroup difference in the level of antioxidants. We suppose that the reason for the increased levels of antioxidants at $33^{\text {rd }}$ pmw in infants with $\mathrm{ROP}$ was in response to oxidative stress.

According to our results, TOS and MDA are good markers of oxidative stress, while TAS and PON1 activity are unreliable in assessing antioxidant protection.

Additional research in this area should contribute to better understanding the pathogenesis of ROP, as well as to development of more effective preventive and therapeutic procedures.

\section{Acknowledgment}

This work was supported by a grant from the Ministry of Education and Science, Republic of Serbia (Project No. 175035).

\section{References}

1. Rahal A, Kumar A, Singh V, Yadav B, Tiwari R, Chakraborty $\mathrm{S}$, et al. Oxidative stress, prooxidants, and antioxidants: the interplay. Biomed Res Int. 2014;2014:761264. PubMed PMID: 24587990; PubMed Central PMCID: PMC3920909, http:// dx. doi.org/10.1155/2014/761264

2. Marseglia L, D’Angelo G, Manti S, Arrigo T, Barberi I, Reiter RI, et al. Oxidative stress-mediated aging during the fetal and perinatal periods. Oxid Med Cell Longev. 2014;2014:8, http:// dx.doi.org/10.1155/2014/358375

3. Ozsurekci Y, Aykac K. Oxidative stress related diseases in newborns. Oxid Med Cell Longev. 2016;2016:2768365, http:// dx.doi.org/10.1155/2016/2768365

4. Banjac L, Bokan V. Retinopathy of prematurity and serum level of insulin-like growth factor-1. Acta Clin Croat. 2012; 51:209-13.

5. Saugstad OD. Oxygen and retinopathy of prematurity. J Perinatol. 2006;26 Suppl 1:S46-50, https://doi.org/10.1038/sj.jp.7211475
6. Smith L. Pathogenesis of retinopathy of prematurity. Pediatrics. 2005;115(4):990-6, http://dx.doi.org/10.1016/j. ghir.2004.03.030

7. Good WV, Hardy RJ, Dobson V, Palmer EA, Phelps DL, Quintos M, et al. The incidence and course of retinopathy of prematurity: findings from the early treatment for retinopathy of prematurity study. Pediatrics. 2005;116(1):15-23, http:// dx.doi.org/10.1542/peds.2004-1413

8. Austeng D, Kallen KB, Hellstrom A, Tornqvist K, Holmstrom GE. Natural history of retinopathy of prematurity in infants born before 27 weeks' gestation in Sweden. Arch Ophthalmol. 2010;128(10):1289-94, https://doi.org/10.1001/archophthalmol.2010.234.

9. Buonocore G, Perrone S, Longini M, Vezzosi P, Marzocchi B, Paffetti $\mathrm{P}$, et al. Oxidative stress in preterm neonates at birth and on the seventh day of life. Pediatr Res. 2002;52:46-9, http://dx.doi.org/10.1203/00006450-200207000-00010

10. Hellstrom A, Perruzzi C, Ju M, Engström E, Hard AL, Liu JL, et al. Low IGF-I suppresses VEGF-survival signaling in retinal endothelial cells: direct correlation with clinical retinopathy of prematurity. Proc Natl Acad Sci USA. 2001;98(10):5804-8. /pnas, http://dx.doi.org/10.1073/pnas.101113998

11. Villegas-Becerril E, González-Fernández R, Perula-Tores L, Gallardo Galera JM. IGF-I, VEGF and bFGF as predictive factors for the onset of retinopathy of prematurity (ROP). Arch Soc Esp Oftalmol. 2006;8:641-6.

12. Garg U, Jain A, Singla P, Sarita Beri S, Garg R, Saili A. Free radical status in retinopathy of prematurity. Indian J Clin Biochem. 2012;27(2):196-9, http://dx.doi.org/10.1007/s12291011-0180-9

13. Erel O. A new automated colorimetric method for measuring total oxidant status. Clin Biochem. 2005;38:1103-11, https:// doi.org/10.1016/j. clinbiochem.2005.08.008

14. Del Rio D, Stewart AJ, Pellegrini N. A review of recent studies on malondialdehyde as toxic molecule and biological marker of oxidative stress. Nutr Metab Cardiovasc Dis. 2005;15:316-28, http://dx.doi.org/10.1016/j.numecd.2005.05.003

15. Dean RT, Fu S, Stoker R, Davies MJ. Biochemistry and pathology of radical-mediated protein oxidation. Biochem J. 1997; 324:1-18.

16. Mendoza-Nunez VM, Ruiz-Ramos M, Sanchez-Rodriguez MA, Retana-Ugalde R, Munoz-Sanchez JL. Aging-related oxidative stress in healthy humans. Tohoku J Exp Med. 2007; 213:261-8

17. Ali A, Zhang Q Lim YK, Fang D, Retnam L, Lim SK. Expression of major HDL- associated antioxidant PON-1 is gender dependent and regulated during inflammation. Free Radic Biol Med. 2003;34:824-9, https://doi.org/10.1016/S0891-5849(02)01436-3

18. Aviram, M, Rosenblat M. Paraoxonases 1, 2, and 3, oxidative stress, and macrophage foam cell formation during atheroscle- 
rosis development. Free Radic Biol Med. 2004;37:1304-16, http://dx. doi.org/10.1016/j. freeradbiomed.2004.06.030

19. Belteki G, Kempster SL, Forhead AJ, Giussani DA, Fowden AL, Curley A, et al. Paraoxonase-3, a putative circulating antioxidant, is systemically up-regulated in late gestation in the fetal rat, sheep, and human. J Clin Endocrinol Metab. 2010; 95:3798-805, https://doi.org/10.1210/jc.2010-0037

20. Parad RB, Allred EN, Rosenfeld WN, Davis JM. Reduction of retinopathy of prematurity in extremely low gestational age newborns treated with recombinant human $\mathrm{Cu} / \mathrm{Zn}$ superoxide dismutase. Neonatology. 2012;102:139-44.

https://doi.org/10.1159/000336639

21. Papp A, Nemeth I, Pelle Z, Tekulics P. Prospective biochemical study of the antioxidant defense capacity in retinopathy of prematurity. Orv Hetil. 1997;138:201-5.

22. Aversa S, Pellegrino S, Barberi I, Reiter RJ, Gitto E. Potential utility of melatonin as an antioxidant during pregnancy and in the perinatal period. J Matern Fetal Neonatal Med. 2012; 25:207-21, http://dx.doi.org/10.3109/14767058.2011.573827

23. Erel O. A novel automated method to measure total antioxidant response against potent free radical reactions. Clin Biochem. 2004;37(2):112-9.

24. Charlton-Menys V, Liu Y, Durrington P. Semiautomated method for determination of serum paraoxonase activity using paraoxon as substrate. Clin Chem. 2006;52:453-7, http:// dx.doi.org/:10.1373/clinchem.2005.063412

25. Kim TI, Sohn J, Pi SY, Yoon YH. Postnatal risk factors of retinopathy of prematurity. Paediatr Perinat Epidemiol. 2004;18: 130-4.

26. Seiberth V, Linderkamp O. Risk factors in retinopathy of prematurity: a multivariate statistical analysis. Ophthalmologica. 2000;214:131-5, https.//doi.org/10.1159/000027482
27. Weinberger B, Laskin DL, Heck DE, Laskin JD. Oxygen toxicity in premature infants. Toxicol Appl Pharmacol. 2002; 181(1):60-7, http://dx. doi.org/10.1006/taap.2002.9387

28. Abdel Ghany EA, Alsharany W, Ali AA, Younass ER, Hussein JS. Anti-oxidant profiles and markers of oxidative stress in preterm neonates. Paediatr Int Child Health. 2016;36(2):134-40, http://dx.doi.org/10.1080/20469047.2015.1109248

29. Jain S, Nair A, Shrivastava Ch. Evaluation of oxidative stress marker malondialdehyde level in the cord blood of newborn infants. Int J Sci Study. 2015;3(6):73-6,

http://dx.doi.org/10.17354/ijss/2015/396

30. Kumar A, Panigrahi I, Basu S, Dash D. Urinary malondialdehyde levels in newborns following delivery room resuscitation. Neonatology. 2008;94(2):96-9, http://dx.doi.org/10.1159/000116633

31. Madoglio RJ, Rugolo LM, Kurokawa CS, Sá MP, Lyra JC, Antunes LC. Inflammatory and oxidative stress airway markers in premature newborns of hypertensive mothers. Braz J Med Biol Res. 2016;49(9):e5160, http://dx.doi.org/10.1590/1414431X20165160

32. Beharry KD, Valencia GB, Lazzaro DR, Aranda JV. Pharmacologic interventions for the prevention and treatment of retinopathy of prematurity. Semin Perinatol. 2016;40(3):189-202, https://doi.org/10.1053/j.semperi.2015.12.006

33. Bozoklu A.O, Sancakdar E, Karakus S, Yildiz C, Akkar I, Arslan M, et al. Evaluation of maternal serum 25-hydroxyvitamin $\mathrm{D}$, paraoxonase 1 levels, and neutrophil-to-lymphocyte ratio in spontaneous preterm birth. Med Sci Monit. 2016;22:1238-43.

34. Sözmen E, Sözmen B, Girgin FK, Delen Y, Azarsiz E, Erdener $\mathrm{D}$, et al. Antioxidant enzymes and paraoxonase show a co-activity in preserving low-density lipoprotein from oxidation. Clin Exp Med. 2001;1:195-9.

Sažetak

\section{PRO-OKSIDANSI I ANTIOKSIDANSI U PREMATURNOJ RETINOPATIJI}

\section{Banjac, G. Banjac, J. Kotur-Stevuljevic, V. Spasojevic-Kalimanovska, T. Gojkovic, N. Bogavac-Stanojević, Z. Jelić-Ivanović i G. Banjac}

Nedonoščad je osobito osjetljiva na oksidacijski stres koji uzrokuje bolesti poput prematurne retinopatije (PR). Oksidacijski stres je neravnoteža između proizvodnje pro-oksidansa i sposobnosti tijela za detoksikaciju njihovih štetnih učinaka antioksidansima. Druga, proliferacijska faza PR započinje oko 33. postmenstrualnog tjedna (pmt). Svrha našega istraživanja bila je procijeniti pro-oksidacijski/antioksidacijski status u nedonoščadi u 33. pmt. U istraživanju je sudjelovalo 59 nedonoščadi. PR je klasificirana prema Međunarodnoj klasifikaciji PR. Totalni oksidacijski status (TOS), totalni antioksidacijski status (TAS), malondialdehid (MDA) i paraoksonaza 1 (PON1) određeni su spektrofotometrijski. Vrijednosti pro-oksidansa TOS i MDA u nedonoščadi s $P R$ bile su značajno više nego u nedonoščadi bez $P R$ ( $p<0,05$ za oba). Nije bilo značajne razlike u vrijednostima TAS i PON1 između nedonoščadi s PR i bez PR. Naše istraživanje je pokazalo da razina pro-oksidansa značajno korelira s razvojem PR, ali nije potvrdilo značajnu razliku u razini antioksidansa između skupina. Prema našim rezultatima TOS i MDA dobri su pokazatelji oksidacijskog stresa, dok su TAS i PON1 nepouzdani u procjeni antioksidacijske zaštite.

Ključne riječi: Reaktivni spojevi kisika; Antioksidansi; Retinopatija nedonořčadi; Nedonǒ̌če; Oksidacijski stres 